\title{
Avaliação Microbiológica de logurte com Leite de Cabra Adicionado de Própolis
}

Anaklaudia Sombra Santos (I), Maria Gilnara Lima Bandeira (I), Lidiana Souza Correia Lima (I), Auriana De Assis Régis (I), Monique

Ellen Torres Da Silva (I), Marlene Nunes Damasceno (I), Pahlevi Augusto De Souza (I), Rinaldo Dos Santos Araújo (I)

(I) IFCE - LIMOEIRO - INSTITUTO FEDERAL DE EDUCAÇÃO, CIENCIA E TECNOLOGIA DO CEARÁ (RUA ESTEVÃO REMIGIO, 1145, CENTRO - LIMOEIRO DO NORTE)

\section{Resumo}

O iogurte é considerado um alimento funcional, pois além de ser amplamente consumido devido ao seu agradável sabor, textura e propriedades nutritivas, é um alimento que pode ser enriquecido com diversos ingredientes fisiologicamente ativos, que têm como principal objetivo melhorar a sua funcionalidade e fornecer benefícios para a saúde. Dentro deste contexto, tem-se observado constante sofisticação tecnológica, com o surgimento crescente de novos produtos no mercado. Diante disso, objetivou-se com o trabalho avaliar microbiologicamente o iogurte com leite de cabra adicionado de própolis. O iogurte foi produzido na cidade de Limoeiro do Norte- CE. O leite de cabra pasteurizado e os iogurtes produzidos foram analisados quanto a contagem de coliformes totais, coliformes termotolerantes e pesquisa de E. coli, contagem de bactérias mesófilas e de Staphylococcus sp. Foi utilizado o método dos tubos múltiplos para determinação de coliformes, utilizando testes presuntivos para a confirmação da presença nas amostras, sendo o teste presuntivo positivo, procederam-se da mesma maneira os testes confirmativos para coliformes totais e termotolerantes com caldo Verde Brilhante Bile 2\% e Caldo EC, respectivamente. Em seguida, foram realizadas as técnicas recomendadas para verificação de bactérias mesófilas, em ágar padrão para contagem em placas (PCA), e de

\footnotetext{
Referência:

Anaklaudia Sombra Santos, Maria Gilnara Lima Bandeira, Lidiana Souza Correia Lima, Auriana De Assis Régis, Monique Ellen Torres Da Silva, Marlene Nunes Damasceno, Pahlevi Augusto De Souza, Rinaldo Dos Santos Araújo. Avaliação Microbiológica de logurte com Leite de Cabra Adicionado de Própolis. In: Anais do 12 Congresso Latinoamericano de Microbiologia e Higiene de Alimentos - MICROAL 2014 [= Blucher Food Science Proceedings, num.1, vol.1]. São Paulo: Editora Blucher, 2014. DOI 10.5151/foodsci-microal-140
} 
Staphylococcus sp. utilizando ágar Baird Parker. As análises seguiram as recomendações da Instrução Normativa $N^{\circ} 62$ do Ministério da Agricultura Pecuária e Abastecimento (BRASIL, 2003). O leite caprino previamente pasteurizado utilizado para a elaboração do iogurte apresentou baixa contagem de coliformes totais e ausência de coliformes termotolerantes, Staphylococcus sp. e bactérias mesófilas. Com isso, o leite caprino utilizado estava de acordo com o limite desses micro-organismos preconizados pela legislação vigente. No iogurte foi observada contagem de coliformes termotolerantes $(0,3 \mathrm{NMP} / \mathrm{mL})$, sendo este ausente na matéria-prima, porém, essa contagem não tornou o iogurte impróprio para consumo, pois o valor encontrado estava dentro dos limites permitidos na legislação. Com os resultados apresentados, pode-se dizer que a pasteurização realizada no leite caprino utilizado como matéria-prima foi eficiente para manter sua carga microbiana dentro dos limites aceitáveis da legislação vigente.

Palavras-Chave: Funcionalidade, Leite de Cabra, Consumidor

Agência de Fomento: CAPES, FUNCAP, CNPq, IFCE-LIMOEIRO DO NORTE 